\title{
RGD Peptide-Grafted Graphene Oxide as a New Biomimetic Nanointerface for Impedance-Monitoring Cell Behaviors
}

\author{
Jianxia Li, ${ }^{1,2,3}$ Leilei Zheng, ${ }^{1,2,3}$ Lin Zeng, ${ }^{1}$ Yan Zhang, ${ }^{1}$ Lin Jiang, ${ }^{1}$ and Jinlin Song ${ }^{1,2,3}$ \\ ${ }^{1}$ College of Stomatology, Chongqing Medical University, Chongqing 401147, China \\ ${ }^{2}$ Chongqing Municipal Key Laboratory of Oral Biomedical Engineering of Higher Education, Chongqing 401147, China \\ ${ }^{3}$ Chongqing Key Laboratory of Oral Diseases and Biomedical Sciences, Chongqing 401147, China \\ Correspondence should be addressed to Jinlin Song; soongjl@163.com
}

Received 11 August 2016; Revised 7 November 2016; Accepted 20 November 2016

Academic Editor: Rajesh R. Naik

Copyright (C) 2016 Jianxia Li et al. This is an open access article distributed under the Creative Commons Attribution License, which permits unrestricted use, distribution, and reproduction in any medium, provided the original work is properly cited.

\begin{abstract}
A new biomimetic nanointerface was constructed by facile grafting the bioactive arginylglycylaspartic acid (RGD) peptide on the graphene oxide (GO) surface through carbodiimide and N-hydroxysuccinimide coupling amidation reaction. The formed RGDGO nanocomposites own unique two-dimensional structure and desirable electrochemical performance. The linked RGD peptides could improve GO's biocompatibility and support the adhesion and proliferation of human periodontal ligament fibroblasts (HPLFs) on RGD-GO biofilm surface. Furthermore the biologically active RGD-GO nanocomposites were demonstrated as a potential biomimetic nanointerface for monitoring cell biobehaviors by electrochemical impedance spectroscopy (EIS). By analysis of the data obtained from equivalent circuit-fitting impedance spectroscopy, the information related to cell membrane capacitance, cell-cell gap resistance, and cell-electrode interface gap resistance in the process of cell adhesion and proliferation could be obtained. Besides, this proposed impedance-based cell sensor could be used to assess the inhibition effect of the lipopolysaccharide (LPS) on the HPLFs proliferation. Findings from this work suggested that RGD peptide functionalized GO nanomaterials may be not only applied in dental tissue engineering but also used as a sensor interface for electrochemical detection and analysis of cell behaviors in vitro.
\end{abstract}

\section{Introduction}

For in vitro cytological analysis, cell adhesion and proliferation behaviors are influenced by the extracellular microenvironment, while the corresponding microenvironment parameters adjustment can show impacts on the biological behaviors of cells $[1,2]$. In order to analyze cell biological behaviors in vitro, the cells need to be cultivated on the surface of support materials owning desirable properties, especially with good biocompatibility. In addition, physical and chemical properties of the support materials, including surface roughness, hydrophilicity, surface chemical functional groups, topological morphology, and surface charge, are able to show great impact on the behaviors of cell adhesion and proliferation on their surface $[3,4]$. Therefore, design and development of a novel biocompatible surface are necessary to facilitate the study of cell behaviors of adhesion and proliferation and attracting great attention.
Graphene oxide (GO), a derivative of graphene, is hydrophilic and owns oxygen-containing functional groups (e.g., hydroxyl, epoxy, carbonyl, and carboxyl) [5-8]. Due to its excellent physicochemical properties, GO is widely used as cell growth interface for in vitro cytological analysis applications [9-11]. In addition, through various chemical modification and functionalization, GO can also be used for electrochemical and biomedical applications [12-15].

On the other hand, arginine-glycine-aspartic acid (RGD) peptide is a kind of well-known targeting ligand, which could effectively enhance $\alpha_{v} \beta_{3}$ integrin-overexpressing tumor cell uptake of RGD-modified nanomaterials [16-22]. In addition, RGD peptide is also known as the cell adhesion peptide, which resides in the cell attachment region of fibronectin and can promote cell adhesion, proliferation, and differentiation [23-28]. As an intensively studied cell binding sequence, RGD peptide functionalized substrates have been 


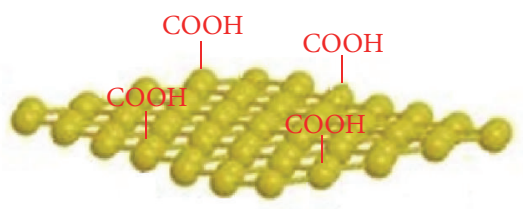

Graphene oxide

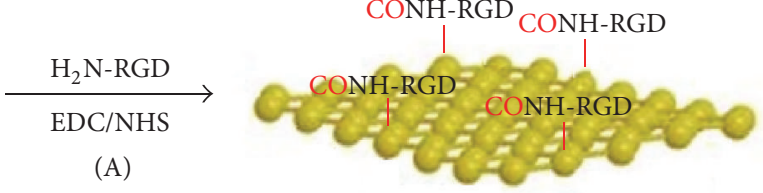

RGD-peptide grafted

Graphene oxide

(B) $\downarrow$ Cell inoculation

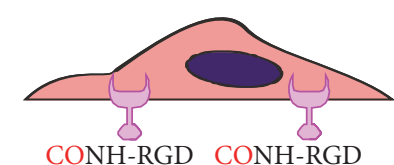

EIS detection

(C)

RGD-GO modified electrode

Cell-based assay

SCHEME 1: Schematic illustration of the preparation of RGD-GO film and its cell-based assay.

developed to enhance the cell behaviors and employed as tissue engineering scaffolds [29-35]. For example, Borchard and coworkers have developed an RGD-functionalized chitosan derivative for enhanced cell adhesion applications [29]. Several RGD-functionalized GO nanomaterials have been developed for biomarker detection [12], molecule analysis [36], and targeted photothermal therapy of cancers [37, 38] and other biomedical applications [14]. However, the current used biological functionalization of graphene oxide requires the introduction of a third linkage [12], which would not only increase the complexity of the experimental procedure, but also may change the physical and chemical properties of GO.

In this present work, RGD-modified GO nanomaterials were developed via the covalent linkage of the carboxyl functional groups on the surface of GO and the amine groups of RGD peptide. This synthesis procedure can not only endow the GO with desirable biocompatibility, but also maintain the physical and chemical properties of GO. Scheme 1 illustrates the modification procedure of RGD peptide onto the GO surface and the following cell analysis experiment. The GO films were firstly formed by natural drying of aqueous solution of GO. Then RGD peptides with amine functional groups were immobilized onto the GO film surface via the EDC/NHS coupling amidation reaction to form RGD-GO nanomaterials. Using human periodontal ligament fibroblasts (HPLFs) as a model, the effect of RGDGO films on cell behaviors of adhesion and proliferation was investigated, which was further compared with that of the unmodified GO control. For further investigating their potential applications in vitro cytological analysis, RGD-GO nanomaterials were modified onto the electrode surface to study the change of electrochemical impedance spectroscopy when HPLFs were cultured on its surface with and without chemical treatment.

\section{Materials and Method}

2.1. Materials. GRGDSP polypeptide sequences containing RGD motif were synthesized by Scilight Biotechnology, LLC (Beijing, China). GO (30-50 nm in diameter) was provided by Nanjing JCNANO Technology Co., LTD. The received GO was dispersed in deionized water with a concentration of $1 \mathrm{mg} \mathrm{mL}^{-1}$ and suffered ultrasonic treatment for 15 minutes before use. DMEM F-12 medium and fetal bovine serum (FBS) were purchased from Gibco (USA). Penicillin/streptomycin was provided by Hyclone. CCK8 assay kit and Actic-Traker Green were purchased from Beyotime Biotechnology. LPS was purchased from SigmaAldrich. All the other reagents obtained from Sigma-Aldrich were of analytical grade and were used as received without further purification. All used solutions were prepared using deionized (DI) water (resistivity higher than $18.0 \mathrm{M} \Omega \mathrm{cm}$ ). ITO conductive glasses were ultrasonic-cleaned for $15 \mathrm{~min}$ in acetone, ethanol, and DI water and dried before use.

2.2. Characterization Technique. Fourier transform infrared spectroscopy (FT-IR) measurements were recorded on a Magma-IR 750 infrared spectrometer. Atomic force microscope (AFM) images were acquired at tapping mode by using Nanoscope III (Veeco Company) with Nanoscopy analysis software. Cell fluorescence images were obtained by confocal microscope (Leica SP8) with a magnification of 100X. 
Electrochemical measurements were performed on a CS315 electrochemical workstation (Correst, Co., Ltd) with a threeelectrode system, in which the modified ITO conductive glass $(1 \mathrm{~mm}$ in diameter) was used as working electrode, $\mathrm{Ag} / \mathrm{AgCl}$ (sat. $\mathrm{KCl}$ ) as reference electrode, and platinum wire as auxiliary electrode.

2.3. Preparation and Characterization of the Biofilms of RGDGO Nanomaterials. Firstly, $100 \mu \mathrm{L}$ of GO aqueous solution $\left(1.0 \mathrm{mg} \mathrm{mL}^{-1}\right)$ was dropped onto the clean surface of ITO conductive glass and then dried under the lamp. Subsequently, $100 \mu \mathrm{L}$ aqueous solution containing $173 \mu \mathrm{M}$ EDC and $15 \mu \mathrm{M}$ NHS was dropped onto the GO surface and left to react for $3 \mathrm{~h}$ to activate the surface $-\mathrm{COOH}$ groups of GO. After that the activated film was gently rinsed with DI water. RGD peptide solution $\left(1 \mathrm{mg} \mathrm{mL}^{-1}\right)$ was dropped onto the activated GO surface and incubated for $4 \mathrm{~h}$. For cell related test, the RGD-GO biofilms were synthesized in 24-well plates and cleaned with sterile DI water before cells were seeded. The morphologies of the GO film before and after modification were characterized by AFM. The chemical compositions of RGD-GO film were detected by FTIR measurements. Meanwhile, the electrochemical properties of RGD-GO biofilms were investigated by electrochemical impedance spectroscopy (EIS), which was performed in $0.01 \mathrm{M}$ PBS. The sine wave with amplitude of $10 \mathrm{mV}$ was used as the excitation signal with the scan frequency range from 1 to $105 \mathrm{~Hz}$. The obtained EIS data were analyzed through the established equivalent circuit using ZView 2.0 software (Scribner Associates, Southern Pines, NC, USA).

2.4. Cell Culture. Human periodontal ligament fibroblasts (HPLFs) were obtained from human periodontal ligament tissue (Affiliated Stomatology Hospital of Chongqing Medical University, China) and were cultured in DMEM F-12 medium supplemented with FBS (10\%) and penicillin/streptomycin (1\%) and incubated at $37^{\circ} \mathrm{C}$ and $5 \% \mathrm{CO}_{2}$ in a humidified atmosphere. After incubation, the cells were collected and redispersed at the density of $1.5 \times 10^{5} / \mathrm{mL}$. Then $100 \mu \mathrm{L}$ cell dispersions were seeded onto the RGD-GO films and cultured for $24 \mathrm{~h}$. After that the nonadherent and dead cells were removed by washing with PBS buffer.

2.5. Cell Viability and Morphology Observation. Cell viability of HPLFs cultured on RGD-GO biofilms was evaluated using the well-established CCK-8 assay. RGD-GO biofilms or GO films were formed in the wells of the plate, followed by washing with sterilized DI water and 30 min UV treatment. Then cells were seeded into 24-well plates and cultured for 2, 24, 48, and $72 \mathrm{~h}$. After primary medium was discarded, the culture medium containing $10 \%$ CCK- 8 was added and incubated for 2 hours. Then $200 \mu \mathrm{L}$ medium was transferred to a new 96well plate. The results were expressed as absorbance values through a microplate reader (Bio-Tek Instruments, Inc.) at the wavelength of $490 \mathrm{~nm}$.

For cell morphology observation to study the cell adhesion and proliferation behaviors, $100 \mu \mathrm{L}$ cell dispersions were seeded onto the RGD-GO-modified cell plate at the density of $1.5 \times 10^{5} / \mathrm{mL}$. After $24 \mathrm{~h}$ incubation, the adhered cells were fixed with $4 \%$ paraformaldehyde for $10 \mathrm{~min}$. Then cytoskeleton and cell nucleus were stained with Actin-Tracker Green and DAPI, respectively. Fluorescence images of the cells were captured using a laser scanning confocal microscope and the data were analyzed by image J software. The cells cultured on GO films treated through the similar protocol were used as control.

2.6. Electrochemical Impedance Analysis. For this test, $100 \mu \mathrm{L}$ of HPLFs dispersions $\left(1.5 \times 10^{5} / \mathrm{mL}\right)$ was dropped onto the surface of RGD-GO-modified ITO electrode, Then the electrode was cultured at $37^{\circ} \mathrm{C}$ and $5 \% \mathrm{CO}_{2}$ in a humidified atmosphere to make the cells adhesion and proliferation for $2,24,48$, and $72 \mathrm{~h}$, respectively. After that the surfaces of the electrode were washed with PBS several times to remove the weakly attached cells and dead cells. EIS was performed in $0.01 \mathrm{M}$ PBS ( $\mathrm{pH}=7.4$ ) buffer. Meanwhile, the RGD-GOmodified ITO electrode without cell seeded was used as a blank control and GO-modified ITO electrode seeded with cells was used as an experimental control.

For analysis of the inhibition effect of LPS on HPLFs proliferation, $1 \mathrm{~mL}$ HPLFs cells $\left(1.0 \times 10^{5}\right.$ cells $\left.\mathrm{mL}^{-1}\right)$ were seeded on the RGD-GO-modified ITO electrode and incubated for 24 hours at $37^{\circ} \mathrm{C}$. Then different concentration of LPS was added into cell and incubated for another 24 hours. Then EIS measurement was conducted in PBS. All EIS measurement parameters and data processing were same as prementioned. The control group was cells without LPS treatment. The LPS induced impedance change was calculated as $1-Z_{t} / Z_{c}$, where $Z_{t}$ is the highest impedance change value at a special frequency for LPS treated group and $Z_{c}$ is for LPS free group. In parallel, the effect of LPS on HPLFs cells viability was analyzed using CCK-8 assay. Briefly, HPLFs were seeded into 96-well plates $\left(1.0 \times 10^{5}\right.$ cells $\left./ \mathrm{mL}\right) ; 24 \mathrm{~h}$ after seeding, cells were treated by different concentration of LPS for 24 hours. Then, $10 \mu \mathrm{L}$ of CCK- 8 solution was added into each well and incubated at $37^{\circ} \mathrm{C}$ for $1 \mathrm{~h}$. The absorbance value was recorded at $450 \mathrm{~nm}$ wavelength with a microplate reader (Varioskan, Thermo Scientific). The relative cell viability was characterized by $1-A_{t} / A_{c}$, where $A_{t}$ and $A_{c}$ refer to absorbance value of LPS treatment group and untreated group, respectively.

\section{Results and Discussion}

3.1. Synthesis and Characterization of RGD-GO Biofilms. The preparation process of RGD-GO biofilms was shown in Scheme 1. The GO films were formed by natural drying of aqueous solution of GO. Then RGD peptides with amino functional groups were immobilized onto the GO film surface owning abundant surface carboxyl groups via the EDC/NHSactivated amidation reaction to form RGD-GO biofilms. Figure 1 shows the AFM images of GO and RGD-GO film deposited onto ITO electrode surface. From Figure 1(a), it can be seen that GO nanosheets were stacked with each other, resulting in a loose and porous structure. It can also be known that the line roughness of GO film was $8.2 \pm$ $0.8 \mathrm{~nm}$, and the surface roughness was $4.2 \pm 0.4 \mathrm{~nm}$. When RGD peptides were covalently bounded onto the GO films, 

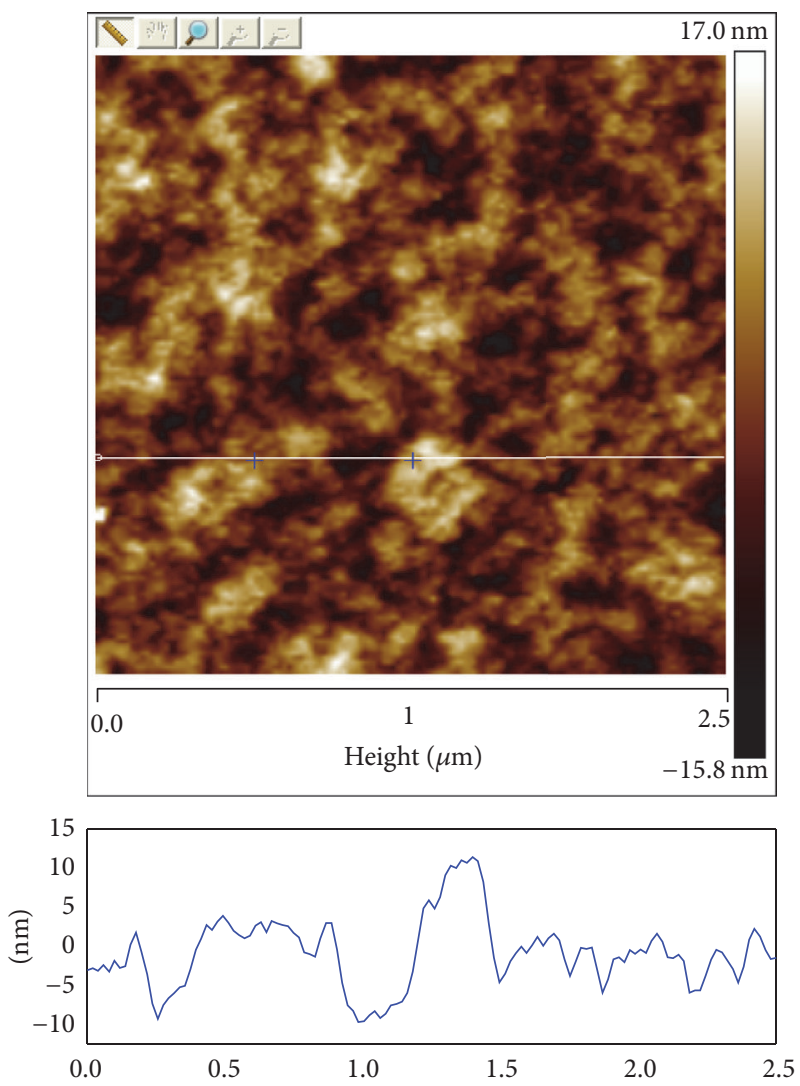

(a)
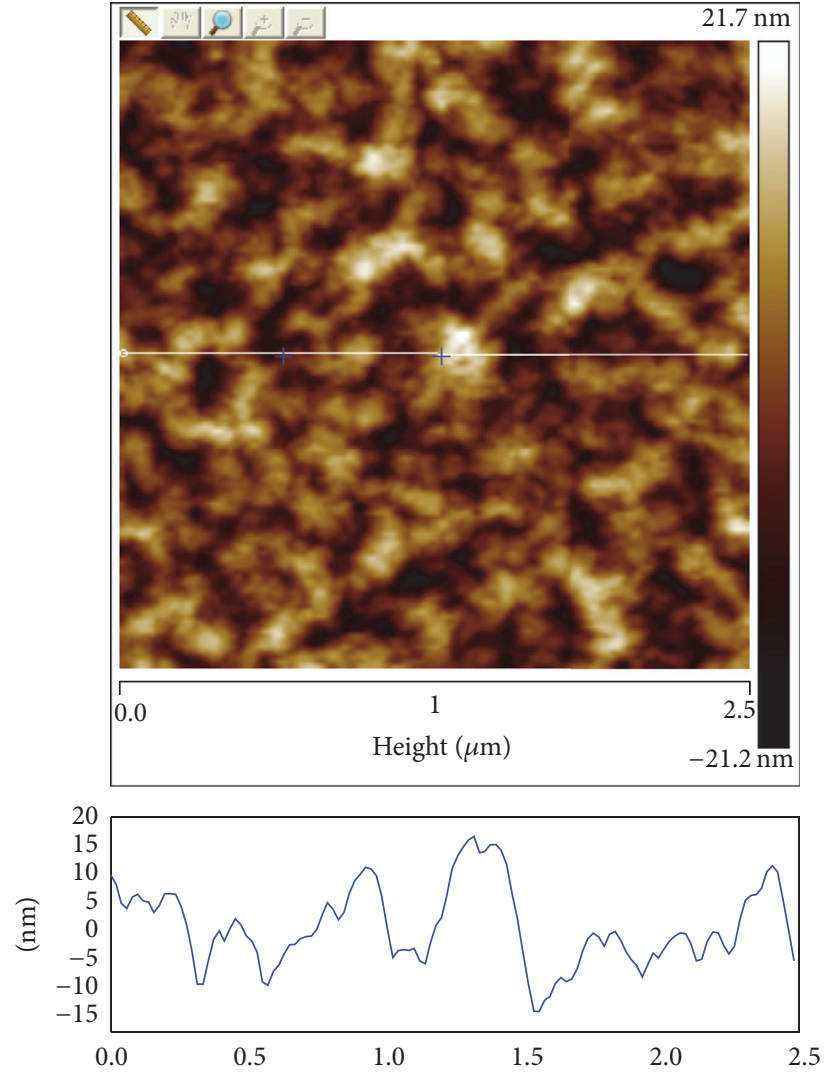

(b)

FIGURE 1: Atomic force microscopy (AFM) images of GO (a) and RGD-GO (b) films deposited onto ITO electrode surfaces.

their surface morphology displayed similar characterization without obvious difference. From the data, it can be known that the line roughness of the formed biofilms was $10.8 \pm$ $1.2 \mathrm{~nm}$, and the surface roughness was $6.6 \pm 0.8 \mathrm{~nm}$. The increase of roughness of the RGD-GO biofilms could be attributed to the surface grafting of RGD peptides.

The covalent bonding of RGD peptides onto the GO surface could be further confirmed by FTIR measurements. Figure 2 shows the FTIR spectra of GO and RGD-GO films. The FTIR spectrum of GO displays several absorption peaks of oxygen-containing functional groups, such as $\mathrm{C}$ $\mathrm{OH}$ stretching vibration peak at $1732 \mathrm{~cm}^{-1}$ and $-\mathrm{OH}$ vibration peak at $3429 \mathrm{~cm}^{-1}$. The peaks at 1078,1396 , and $1630 \mathrm{~cm}^{-1}$ were attributed to the absorption peak of epoxy group (C-O-C), O-H deformation, and carbonyl group $(\mathrm{C}=\mathrm{O})$, respectively [39]. By contrast, the FTIR spectrum of RGDGO biofilms clearly displayed two new peaks at 1533 and $1290 \mathrm{~cm}^{-1}$, corresponding to the characteristic peaks of amide I and amide II of the RGD peptides [40]. It was also noticed that the absorption peak at $1732 \mathrm{~cm}^{-1}$ assigned to carboxyl groups $(\mathrm{C}-\mathrm{OH})$ became weak. This may provide another evidence for the successful modification of RGD peptide, during which process many of the surface carboxyl groups of GO films would be consumed.

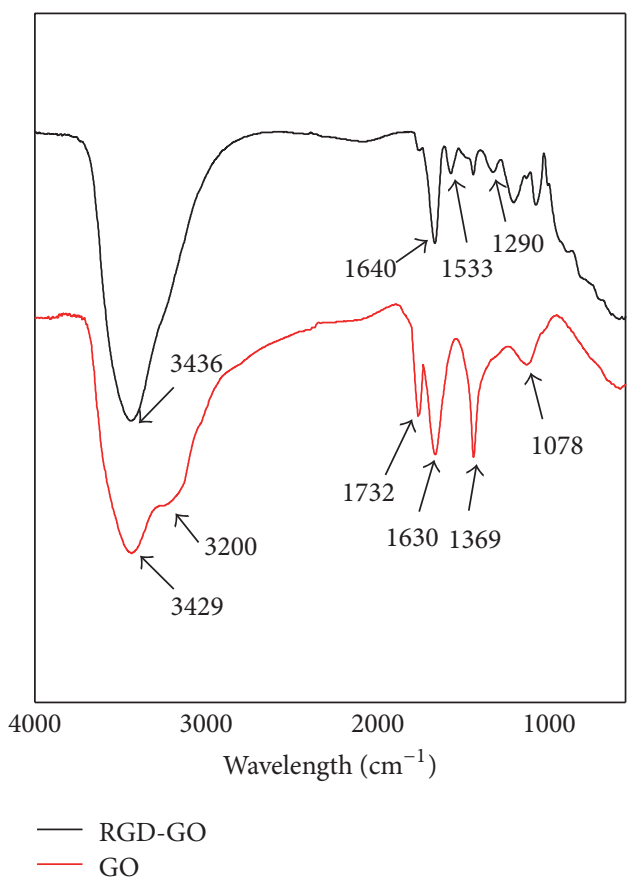

FIGURE 2: FTIR spectra of GO and RGD-GO film. 


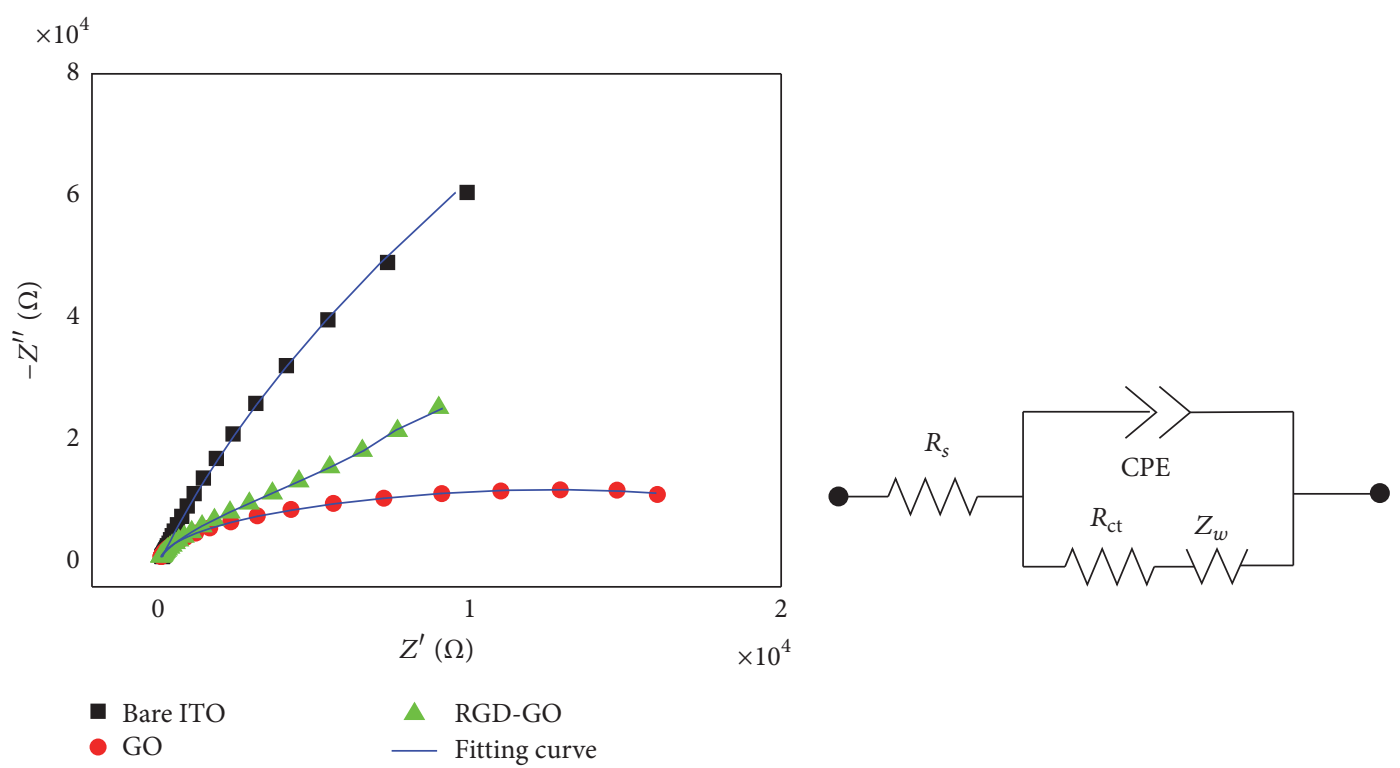

(a)

(b)

\begin{tabular}{lccccccc}
\hline Elements & $R_{s}$ & CPE- $T$ & CPE- $P$ & $R_{\mathrm{ct}}$ & $Z_{w}-R$ & $Z_{w}-T$ & $Z_{w}-P$ \\
\hline ITO & 249.8 & $2.8 E-6$ & 0.94 & $1.0 E 6$ & 0 & $9.5 E-5$ & 0.43 \\
GO & 209.5 & $3.6 E-6$ & 0.94 & $2.1 E 4$ & 12060 & 0.34 & 0.64 \\
RGD-GO & 205.9 & $5.3 E-6$ & 0.9 & $4.7 E 4$ & 6174 & 0.01 & 0.45 \\
\hline
\end{tabular}

(c)

FIGURE 3: (a) EIS characterization of unmodified, GO-modified, and RGD-GO-modified ITO electrode. (b) A diagram of the equivalent circuit. Wherein $R_{s}$ represents the ohmic resistance of the electrolyte solution, $R_{\mathrm{ct}}$ represents charge transfer resistance, CPE represents constant phase element $\left(Z_{\mathrm{cpe}}=1 / Q\left(j_{w}\right)^{n}\right)$, and $Z_{w}$ represents Warburg impedance. (c) Fitted values of the equivalent circuit elements.

The EIS measurement is a noninvasive material interface analysis tool since it uses low amplitude AC voltage $(\sim 10 \mathrm{mV})$ as the detection excitation signal [41, 42]. Figure 3(a) shows EIS complex curves of the bare ITO electrode, GO-modified ITO electrode, and RGD-GO-modified ITO electrode. The results for these three electrodes showed distinguishable difference, indicating that each electrode owned distinct electrode impedance property. To figure this out, Randle's equivalent circuit (with Warburg element equivalent circuit) was employed for fitting the impedance spectroscopy data (Figure 3(b)). Randle's equivalent circuits are usually used to explain the electrode interface system containing bilayer capacitance and Faraday impedance [43].

Herein, taking into account of the film surface roughness, the interference of electrolyte composition to reaction rate, the uneven current distribution produced by nonstandard electrode placement, and so on, constant phase element was used to replace traditional Randle's equivalent circuit in order to obtain a better fitting [44]. Wherein, $R_{s}$ represented the ohmic resistance of the electrolyte solution, $R_{\mathrm{ct}}$ represented charge transfer resistance, CPE represented constant phase element $\left(Z_{\text {cpe }}=1 / Q\left(j_{w}\right)^{n}\right)$, and $Z_{w}$ represented Warburg impedance. By fitting the EIS data with equivalent circuit, the values of respective elements corresponding to each electrode were obtained. Figure 3(c) shows that there was an obvious change in $R_{\mathrm{ct}}$ and CPE- $T$. When the GO films were deposited onto the ITO electrode surface, the $R_{\mathrm{ct}}$ value decreased from $1.0 E 6 \Omega$ to $2.1 E 4 \Omega$, and the CPE- $T$ value increased from $2.8 E-6 \mathrm{C}$ to $3.6 E-6 \mathrm{C}$. This could be attributed to the fact that the deposition of GO improved the dielectric constant and increased the surface area of electrode-electrolyte interface bilayer capacitance. In RGD-GO case, the $R_{\mathrm{ct}}$ value increased to $4.7 E 4 \Omega$ compared to that of the GO-modified electrode. This may be caused that the negatively charged RGD peptides repelled electron transfer via electrostatic force. Meanwhile, the CPE- $T$ value further increased to $5.3 E-6 \mathrm{C}$, indicating the further increase of the dielectric constant and the electrode interface area. These results were consistent with the obtained AFM images. These results not only confirmed the successful modification of RGD-GO films onto the electrodes, but also made it possible to realize the quality control of the manufacturing process of the RGD-GO-modified electrodes.

3.2. Cell Viability and Morphology Observation. The biocompatibility of RGD-GO biofilms was investigated by cell viability test and cell morphology observation. The results of cell viability for HPLFs cultured on the GO films and RGD-GO biofilms were shown in Figure 4. It can be seen that cell viability gradually increased with the culture time, indicating that both GO films and RGD-GO biofilms had 


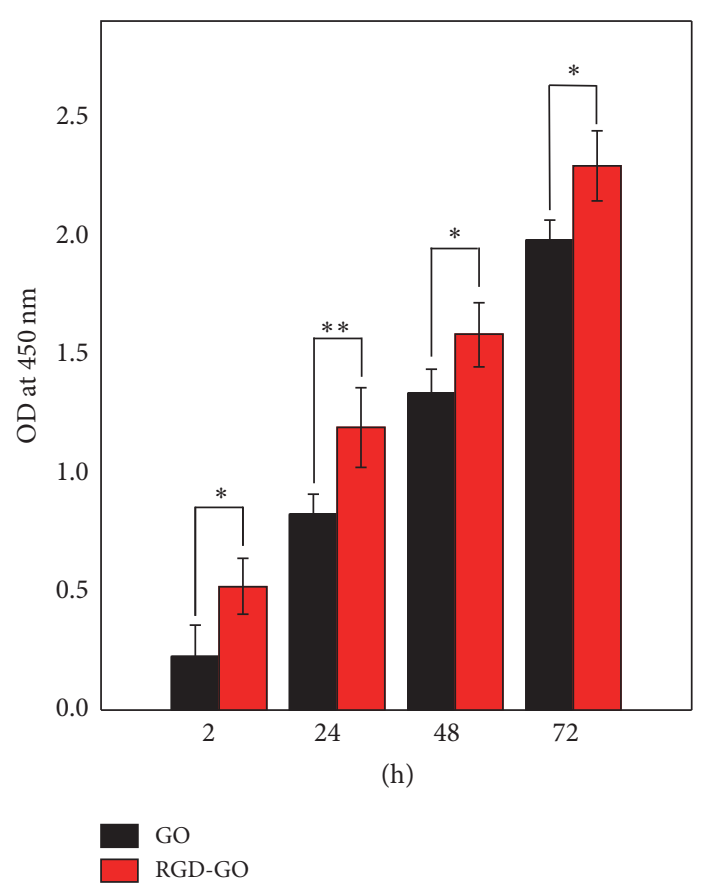

FIGURE 4: A CCK-8 assay of HPLFs cell viability after being cultured on the GO films or RGD-GO films for different time periods. Statistical significance: ${ }^{*} p<0.05$ and ${ }^{* *} p<0.01$.

good biocompatibility. In addition, HPLFs on RGD-GO biofilms showed better cell viability than that of GO films with significant difference.

Cell morphology was further studied to confirm the biocompatibility of the formed films. As shown in Figure 5(a), cells fully spread on the surface of both films and exhibited well-structured cytoskeletons. The adhesion and proliferation ability of HPLFs were significantly improved by the modification of RGD peptide. The cell spreading area and cell density cultured on RGD-GO biofilms were showing significant difference when compared to that of on GO films (Figures 5(b) and 5(c)). These results suggested RGD-GO biofilms could enhance adhesion and proliferation behaviors of HPLFs more effectively than GO films. This could be attributed to the immobilized RGD peptides, which owned good biocompatibility and could endow GO films biomimetic functions. The RGD peptides could act as cell binding points to fulfill the role of extracellular matrix supporting the biological behavior of cells, which could increase the cell capture ability of the films and further promote cell adhesion and proliferation.

\subsection{Preliminary Application of RGD-GO for Impedance-} Monitoring Cell Behaviors. For this analysis, it is a prerequisite that HPLFs could be cultured onto the RGD-GOmodified ITO electrode. The morphologies of HPLFs cultured on the functionalized electrode for different times were observed using microscope (Figure 6). It can be seen that after $2 \mathrm{~h}$ incubation HPLFs displayed a successful adhesion onto the surface of the RGD-GO-modified ITO electrode.
With the increase of the incubation time, cells extended pseudopodia and started spreading. The cells completely spread after $24 \mathrm{~h}$ incubation and showed good proliferation after $48 \mathrm{~h}$ incubation. The density of HPLFs obviously increased after $72 \mathrm{~h}$ incubation and no apoptosis was observed.

3.4. Cell Proliferation Detection. In vitro assessment of cell proliferation is the most basic experiment for tissue engineering $[45,46]$. EIS is simpler and allows direct assessment compared with traditional cell growth assays such as MTT, BrdU labeling, and trypan blue staining. The basic principle and more details of EIS for monitoring the changes during cells adhesion and proliferation have been reported [47, 48]. Cells adhesion and growth on the surface of a planer electrode can hinder unrestricted current flow from the electrode into the electrolyte and increase the overall electrode impedance like insulating particles $[49,50]$. When the frequency of the ac signal is sufficiently high, a certain amount of current can capacitively couple through the plasma membranes and get across the cell layer on transcellular pathways. However, for most low frequency, the current has to bypass the cellular bodies. Accordingly, trans- and paracellular currents impedance originate not only from the plasma membrane together with the integrity of intercellular tight junction, but also from the cell-substrate adhesion zone. Comparing with the well-developed transepithelial/transendothelial electrical resistance (TEER), used only for measurement the cell barrier integrity of endothelial and epithelial monolayer [51, 52], EIS can obtain more integrated information of cell morphological changes during the overall process of cell adhesion, spreading, and proliferation on the surface of specific substrates. In addition, since the trans- and paracellular impedance are dependent on the frequency of the ac signal, they can be separated and quantified individually by fitting the experimental impedance data to a mathematical model. In this study, based on its excellent biocompatibility and special electrochemical property, RGD-GO film was employed as a sensor interface, instead of traditional gold-film electrode; for impedance-monitoring HPLFs proliferation (Figure 7(a)) is a Nyquist plot of RGD-GO-modified electrode system with HPLFs cultured on its surface for different incubation times. It can be seen that the charge transfer control feature semicircle significantly changed in the high frequency region of impedance spectroscopy with HPLFs adhesion and proliferation on the electrode surface. The diameter of the semicircle increased with the process of cell proliferation (Figure 7(a)). For the control group, the impedance spectroscopy of blank electrodes did not show charge transfer control feature semicircle after incubation in culture medium at different times (Figure 7(b)). These results suggested that the change of impedance was caused by the cell adhesion and proliferation behaviors. The appearance of EIS charge transfer control feature semicircular was related to plasma membrane capacitance characteristics and poor conductivity of the cells on the electrode surface [53]. Meanwhile, the behaviors of cell adhesion and proliferation on the electrode interface could increase the resistance of electron transfer and slow down the speed of charge transfer, making this a feasible method to take 

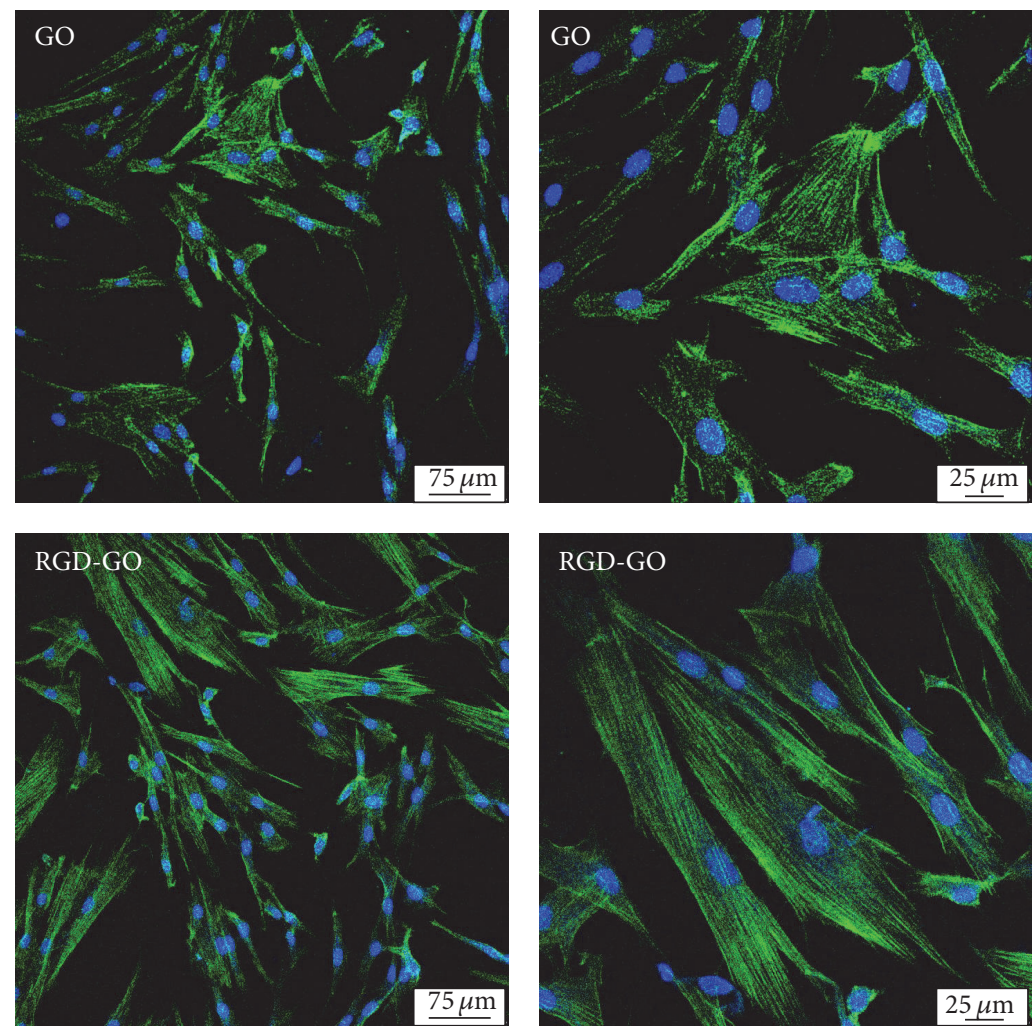

(a)

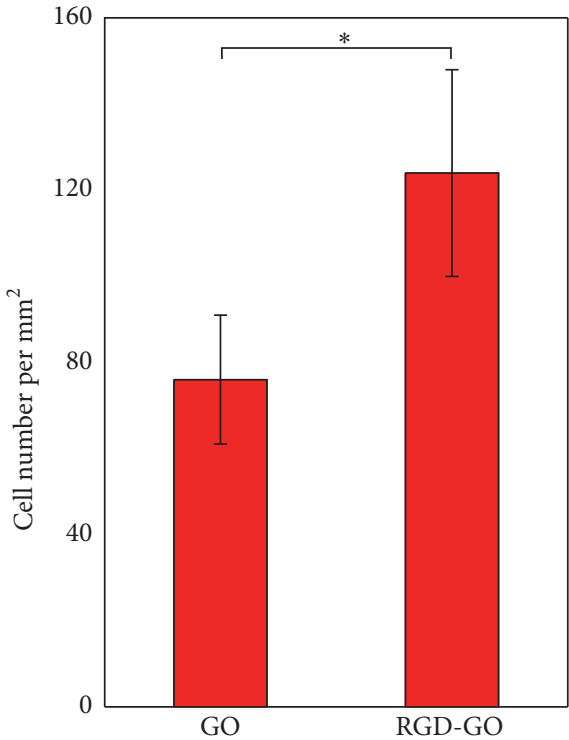

(b)

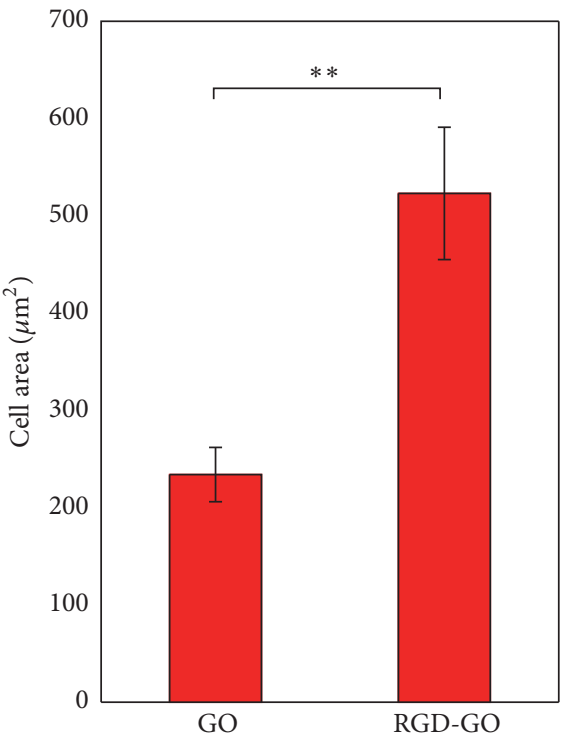

(c)

FIGURE 5: (a) Fluorescence microscopy images of HPLFs cultured on GO films or RGD-GO films for $24 \mathrm{~h}$. The cell nucleus and cytoskeleton were indicated using blue and green, respectively. Quantitative analysis of cell number per unit area $(n=3)(\mathrm{b})$ and cell spreading area $(n=3)$ (c). Statistical significance: ${ }^{*} p<0.05$ and ${ }^{* *} p<0.01$.

advantage of impedance spectroscopy to study cell behaviors $[50,54]$.

Then, the equivalent circuit model was used to quantify the cell adhesion and proliferation behaviors on the ITO electrode. According to the change of impedance spectroscopy before and after cell incubation, cells were equivalent to a circuit that was connected in series by a $R_{C}$ parallel circuit and a $R$ component. RGD-GO-modified ITO electrode was fitted by an equivalent circuit of Randle's circuit containing the Warburg resistance element. So the whole electrode system 

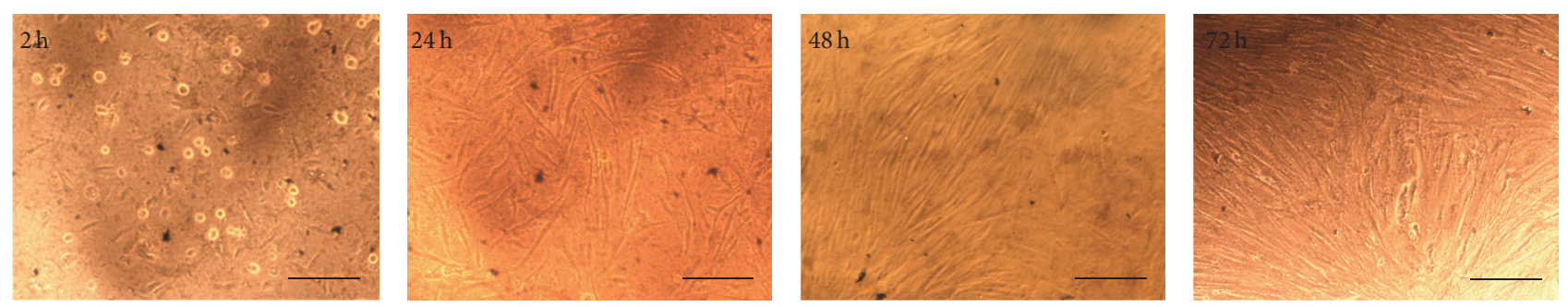

Figure 6: Microscopic images of HPLFs cultured on RGD-GO-modified ITO electrode at different incubation times. Scale bar represents $100 \mu \mathrm{m}$.

could be considered as an equivalent circuit connected in series by the electrode equivalent circuit and the cell equivalent circuit (Figure $7(\mathrm{c})$ ). Where $R_{s}^{\prime}$ was cell-electrode gap resistance, $R_{\text {cell }}$ was intercellular resistance and $C_{\text {cell }}$ was cell membrane capacitance.

The impedance data were analyzed using the nonlinear least squares curve fitting method, as depicted in Figure 7(d). With the adhesion and proliferation of cells on the RGD-GOmodified ITO electrode surface, the values of $C_{\text {cell }}$ rapidly decreased within the incubation time of $2-24 \mathrm{~h}$. This value reached to a stable range of 8.2 to $8.5 \mathrm{nF}$ when cells completely spread out to form cell monolayer at the incubation time of $48-72 \mathrm{~h}$. The final value was just slightly higher than that of the GO-modified ITO electrode, which was stable at the range of 7.6-8.1 $\mathrm{nF}$. This change was effected by cell thickness, cell spreading area, and the number of ion channels of cells [55]. In addition, with HPLFs adhesion and proliferation on the RGD-GO-modified ITO electrode surface, the value of $R_{s}^{\prime}$ sustained increasing and reached to a maximum value around $338 \Omega$ after $72 \mathrm{~h}$ incubation. Since $R_{s}^{\prime}$ value reflects the gap resistance between cell and electrode surface, the larger the $R_{s}^{\prime}$ value, the smaller the gap between cell and electrode surface, indicating the strength of the cell behaviors of adhesion and proliferation $[56,57]$. The measured $R_{s}^{\prime}$ value of the RGD-GO-modified ITO electrode surface was higher than that of the GO-modified ITO electrode, indicating that RGD modification could enhance the cell behaviors and the related biomimetic capacity properties of the electrode. The value of $R_{\text {cell }}$ continued to increase with incubation time for both electrodes, which indicated that the gap between cells became narrow, and the degree of cell proliferation increased [56]. The measured $R_{\text {cell }}$ values of the RGD-GO-modified ITO electrode were higher than that of the GO-modified ITO electrode, especially at the incubation time of $48 \mathrm{~h}$. At the formation of cells monolayer at $72 \mathrm{~h}, R_{\text {cell }}$ reached to the maximum value of $1382 \Omega$ for the RGD-GO-modified ITO electrode. These results suggested that cells displayed a better proliferative activity on the RGD-GO-modified ITO electrode surface than on the GO-modified surface, which was in accordance with the previous data of cell counting. The formed RGD-GO biofilms could be used as a promising electrochemical impedance detection interface.

3.5. Assay of the Inhibition Effect of LPS on HPLFs Proliferation. LPS is one of the most primary aetiological agents known to associate with deep periodontal tissues destruction and periodontal disease $[58,59]$. HPLFs are the main part of the periodontal ligament which protects the roots of the tooth and anchor them to the jaws. Therefore, understanding the inhibition effect of the LPS on the HPLFs proliferation is meaningful. In this work, for demonstrating the versatility of the proposed RGD-GO film based EIS sensors, LPS was used as a model to investigate the effect of LPS on HPLFs proliferation. The Nyquist plots responses and impedance frequency responses for LPS treatments were recorded and shown in Figures 8(a) and 8(b), respectively. Concentrationdependent inhibition effect on LPS proliferation could be observed by comparing the diameter of the well-defined semicircle at high frequency in Nyquist plots and impedance value at special frequency in Bode plots. With the increase of LPS concentration, the diameter of the semicircle decreased and the overall impedance value decreased as well, which was due to the constriction of cell plasma membrane and cell detachment from the electrode surface under the condition of cell apoptosis induced by LPS. Additionally, the quantification of the inhibition effect of LPS can be calculated from the maximum impedance changes at a frequency of $1.15 \mathrm{kHz}$, and the relationship curves between the relative cell viability and concentration of LPS were shown in Figure 8(c). From Figure 8(c), it can be seen that the obtained EIS results show similar trend with those from traditional colorimetric CCK- 8 assay. However, some slight differences between the two results existed and the underlying cause has yet be fully elucidated, but two main hypotheses presented. Firstly, the proposed EIS cell biosensor used the biomimetic RGDGO film as the cell growth substrate, while CCK-8 assay adopted polystyrene as the cell growth substrate. The different biophysical-chemical properties of both substrates might regulate cell activity and in turn affect cellular response to LPS. Secondly, the essential difference between these two methods, that is, one based on morphological changes of cells immobilized on electrode surface and the other based on the enzymatic cleavage of the CCK- 8 to formazan by cellular mitochondrial dehydrogenases present in viable cells, might be the primary cause for the difference between results. Therefore, for obtaining more reliable results using the proposed EIS cell sensor, control experiments, parallel groups, and strict quality control are needed. Furthermore, despite their diversity, the proposed EIS cell biosensor has several advantages over traditional optical methods, including lowcost (not needing much more expensive instruments and reagents), noninvasive, laborsaving, and higher precision 


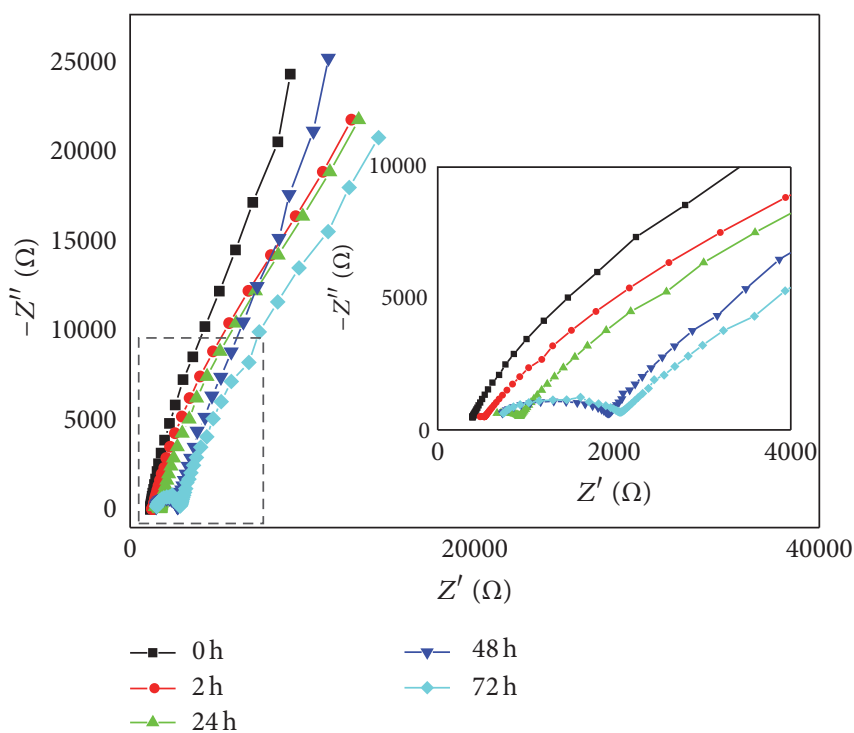

(a)

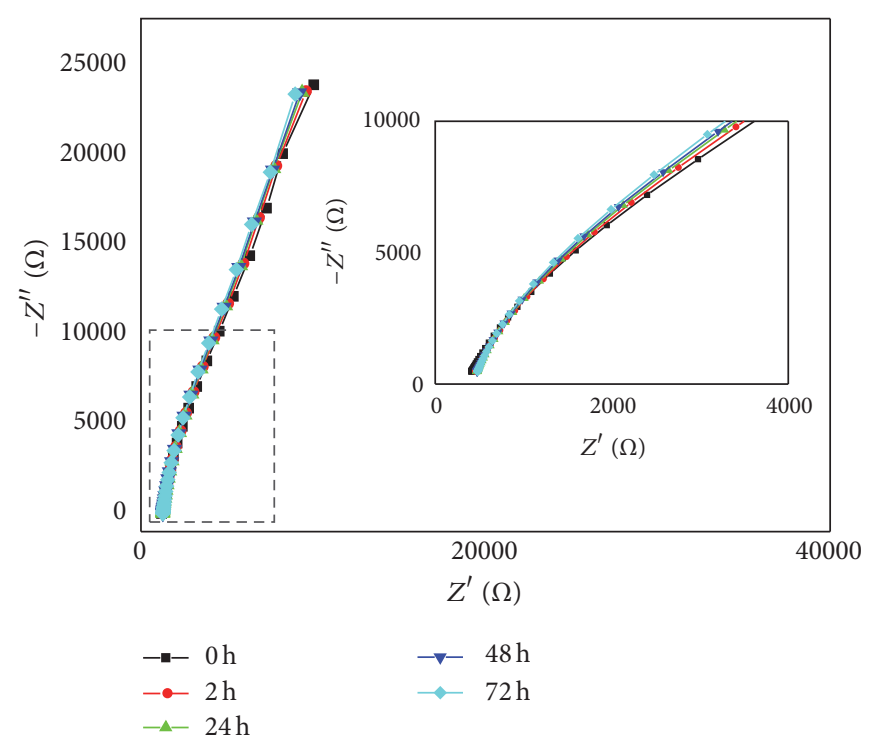

(b)

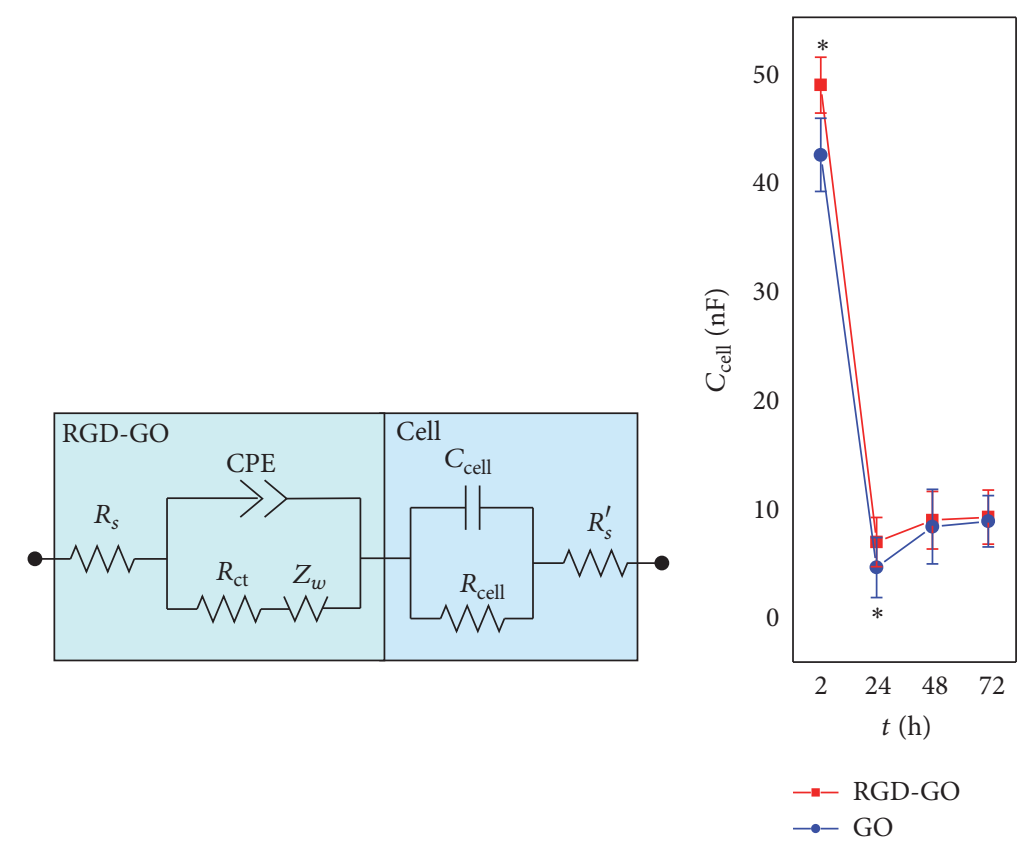

(c)

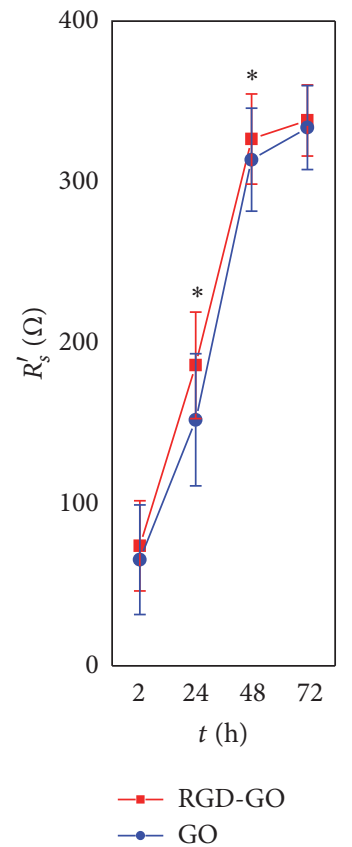

(d)

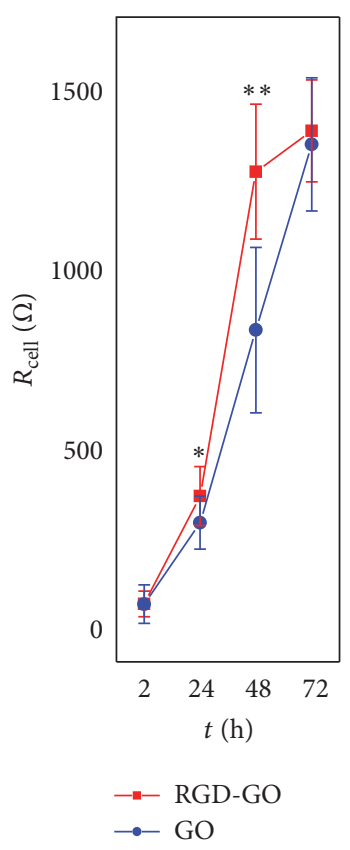

- GO

FIGURE 7: EIS of the RGD-GO-modified (a) with HPLFs cultured on their surfaces for different times and blank GO-modified ITO electrodes. (b) Equivalent circuit model connected in series for the RGD-GO-modified ITO electrode (c, left) and for the HPLFs (c, right). (d) Equivalent circuit model fitted values of the RGD-GO-modified and GO-modified ITO electrodes $(n=3)$. Statistical significance: ${ }^{*} p<0.05$ and ${ }^{* *} p<0.01$.

(RSD $<5 \%$ for the proposed EIS cell sensor versus RSD $<10 \%$ for CCK-8 assays).

\section{Conclusion}

In this reported work, RGD-modified GO nanomaterials were successfully synthesized and characterized. The resulting RGD-GO possesses good stability and special electrochemical property and promotes the adhesion and proliferation behaviors of HPLFs. As a preliminary application, the formed RGD-GO nanomaterials can be deposited onto the ITO electrode and possess the potential as a nanointerface for studying the adhesion and proliferation behaviors of HPLFs by EIS technique. Besides, the inhibition effect of the LPS on the HPLFs proliferation has been demonstrated. Therefore, the RGD-GO nanomaterial can be used not only as a scaffolder for dental tissue engineering, but also as a promising biosensor interface to study the physiological and pathological behavior of living cells. 


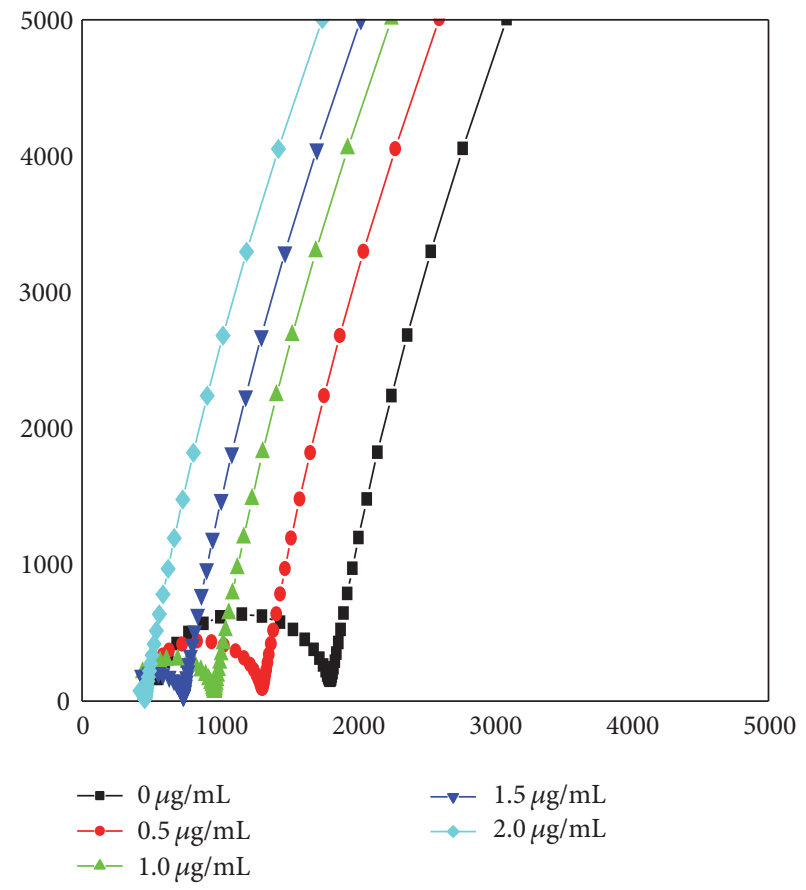

(a)

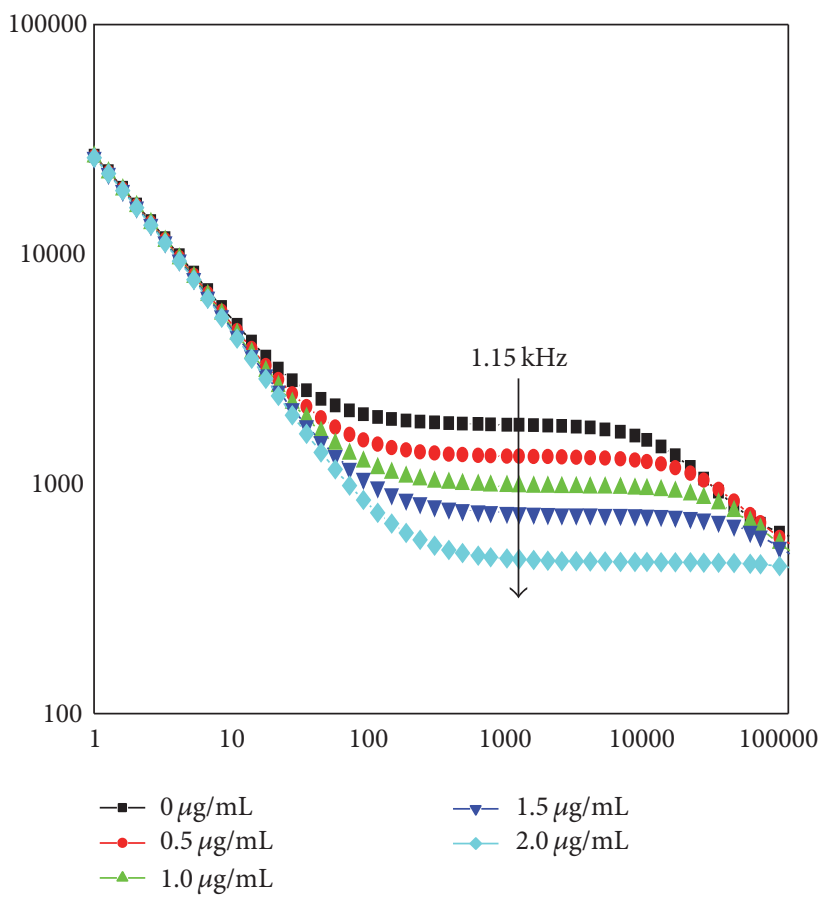

(b)

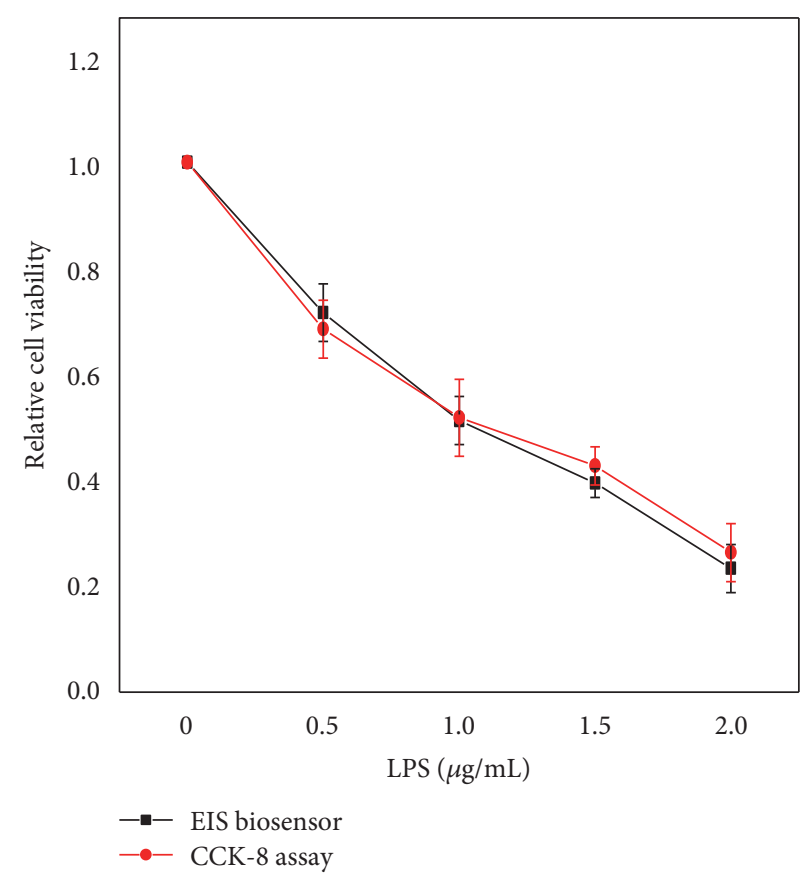

(c)

FIGURE 8: EIS detection of inhibition effect of the LPS on the HPLFs proliferation on RGD-GO-modified ITO microelectrode. (a) Nyquist plots responses recorded after addition of LPS with different final concentrations for $24 \mathrm{~h}$. (b) Impedance frequency responses recorded after addition of LPS with different final concentrations for $24 \mathrm{~h}$. The arrow shows the frequency where the maximum impedance change is induced by LPS. (c) Inhibition effect of the LPS on the HPLFs determined by the proposed EIS cell biosensor and colorimetric CCK-8 assay. $(n=5)$.

\section{Competing Interests}

The authors declare that there are no competing interests regarding the publication of this paper.

\section{Acknowledgments}

Lin Zeng is thankful for the support of Health Bureau of Chongqing (20142134). 


\section{References}

[1] A. Laperle, K. S. Masters, and S. P. Palecek, "Influence of substrate composition on human embryonic stem cell differentiation and extracellular matrix production in embryoid bodies," Biotechnology Progress, vol. 31, no. 1, pp. 212-219, 2015.

[2] M. Herklotz, M. C. Prewitz, C. M. Bidan, J. W. C. Dunlop, P. Fratzl, and C. Werner, "Availability of extracellular matrix biopolymers and differentiation state of human mesenchymal stem cells determine tissue-like growth in vitro," Biomaterials, vol. 60, pp. 121-129, 2015.

[3] D. Du, J. Cai, H. Ju et al., "Construction of a biomimetic zwitterionic interface for monitoring cell proliferation and apoptosis," Langmuir, vol. 21, no. 18, pp. 8394-8399, 2005.

[4] G. Liu, H. Yang, X. M. Zhang, Y. Shao, and H. Jiang, "MR imaging for the longevity of mesenchymal stem cells labeled with poly-L-lysine-Resovist complexes," Contrast Media and Molecular Imaging, vol. 5, no. 2, pp. 53-58, 2010.

[5] B. Li, G. Pan, N. D. Avent, R. B. Lowry, T. E. Madgett, and P. L. Waines, "Graphene electrode modified with electrochemically reduced graphene oxide for label-free DNA detection," Biosensors and Bioelectronics, vol. 72, pp. 313-319, 2015.

[6] D. R. Dreyer, S. Park, C. W. Bielawski, and R. S. Ruoff, "The chemistry of graphene oxide," Chemical Society Reviews, vol. 39, no. 1, pp. 228-240, 2010.

[7] Y. Zhu, S. Murali, W. Cai et al., "Graphene and graphene oxide: synthesis, properties, and applications," Advanced Materials, vol. 22, no. 35, pp. 3906-3924, 2010.

[8] O. C. Compton and S. T. Nguyen, "Graphene oxide, highly reduced graphene oxide, and graphene: versatile building blocks for carbon-based materials," Small, vol. 6, no. 6, pp. 711723, 2010.

[9] W. C. Lee, C. H. Y. X. Lim, H. Shi et al., "Origin of enhanced stem cell growth and differentiation on graphene and graphene oxide," ACS Nano, vol. 5, no. 9, pp. 7334-7341, 2011.

[10] Y. Chang, S.-T. Yang, J.-H. Liu et al., "In vitro toxicity evaluation of graphene oxide on A549 cells," Toxicology Letters, vol. 200, no. 3, pp. 201-210, 2011.

[11] X. Sun, Z. Liu, K. Welsher et al., "Nano-graphene oxide for cellular imaging and drug delivery," Nano Research, vol. 1, no. 3, pp. 203-212, 2008.

[12] Z. Wang, P. Huang, A. Bhirde et al., "A nanoscale graphene oxide-peptide biosensor for real-time specific biomarker detection on the cell surface," Chemical Communications, vol. 48, no. 78, pp. 9768-9770, 2012.

[13] D. Zhang, Y. Zhang, L. Zheng, Y. Zhan, and L. He, "Graphene oxide/poly-l-lysine assembled layer for adhesion and electrochemical impedance detection of leukemia K562 cancer cells," Biosensors and Bioelectronics, vol. 42, no. 1, pp. 112-118, 2013.

[14] C. Wang, B. Chen, M. Zou, and G. Cheng, "Cyclic RGDmodified chitosan/graphene oxide polymers for drug delivery and cellular imaging," Colloids and Surfaces B: Biointerfaces, vol. 122, pp. 332-340, 2014.

[15] W. Qi, W. Yuan, J. Yan, and H. Wang, "Growth and accelerated differentiation of mesenchymal stem cells on graphene oxide/poly-L-lysine composite films," Journal of Materials Chemistry B, vol. 2, no. 33, pp. 5461-5467, 2014.

[16] Q. Chen, H. Wang, H. Liu et al., "Multifunctional dendrimerentrapped gold nanoparticles modified with RGD peptide for targeted computed tomography/magnetic resonance dualmodal imaging of tumors," Analytical Chemistry, vol. 87, no. 7, pp. 3949-3956, 2015.
[17] R. Shukla, T. P. Thomas, J. Peters, A. Kotlyar, A. Myc, and J. R. Baker Jr., "Tumor angiogenic vasculature targeting with PAMAM dendrimer-RGD conjugates," Chemical Communications, no. 46, pp. 5739-5741, 2005.

[18] R. J. Kok, A. J. Schraa, E. J. Bos et al., "Preparation and functional evaluation of RGD-modified proteins as $\alpha \mathrm{v} \beta 3$ integrin directed therapeutics," Bioconjugate Chemistry, vol. 13, no. 1, pp. 128-135, 2002.

[19] Z. Li, P. Huang, X. Zhang et al., "RGD-conjugated dendrimermodified gold nanorods for in vivo tumor targeting and photothermal therapy," Molecular Pharmaceutics, vol. 7, no. 1, pp. 94-104, 2010.

[20] X. He, C. S. Alves, N. Oliveira et al., "RGD peptide-modified multifunctional dendrimer platform for drug encapsulation and targeted inhibition of cancer cells," Colloids and Surfaces B: Biointerfaces, vol. 125, pp. 82-89, 2015.

[21] J. L. Santos, D. Pandita, J. Rodrigues et al., "Receptor-mediated gene delivery using PAMAM dendrimers conjugated with peptides recognized by mesenchymal stem cells," Molecular Pharmaceutics, vol. 7, no. 3, pp. 763-774, 2010.

[22] L. Pan, J. Liu, Q. He, and J. Shi, "MSN-mediated sequential vascular-to-cell nuclear-targeted drug delivery for efficient tumor regression," Advanced Materials, vol. 26, no. 39, pp. 67426748, 2014.

[23] M. Dettin, A. Zamuner, M. Roso et al., "Facile and selective covalent grafting of an RGD-peptide to electrospun scaffolds improves HUVEC adhesion," Journal of Peptide Science, vol. 21, no. 10, pp. 786-795, 2015.

[24] F. Yang, C. G. Williams, D.-A. Wang, H. Lee, P. N. Manson, and J. Elisseeff, "The effect of incorporating RGD adhesive peptide in polyethylene glycol diacrylate hydrogel on osteogenesis of bone marrow stromal cells," Biomaterials, vol. 26, no. 30, pp. 59915998, 2005.

[25] U. Hersel, C. Dahmen, and H. Kessler, "RGD modified polymers: biomaterials for stimulated cell adhesion and beyond," Biomaterials, vol. 24, no. 24, pp. 4385-4415, 2003.

[26] S. L. Bellis, "Advantages of RGD peptides for directing cell association with biomaterials," Biomaterials, vol. 32, no. 18, pp. 4205-4210, 2011.

[27] K. Anselme, "Osteoblast adhesion on biomaterials," Biomaterials, vol. 21, no. 7, pp. 667-681, 2000.

[28] M. M. Stevens and J. H. George, "Exploring and engineering the cell surface interface," Science, vol. 310, no. 5751, pp. 1135-1138, 2005.

[29] A. Hansson, N. Hashom, F. Falson, P. Rousselle, O. Jordan, and G. Borchard, "In vitro evaluation of an RGD-functionalized chitosan derivative for enhanced cell adhesion," Carbohydrate Polymers, vol. 90, no. 4, pp. 1494-1500, 2012.

[30] Y. C. Shin, J. H. Lee, L. Jin et al., "Cell-adhesive matrices composed of RGD peptide-displaying M13 bacteriophage/poly(lactic-co-glycolic acid) nanofibers beneficial to myoblast differentiation," Journal of Nanoscience and Nanotechnology, vol. 15, no. 10, pp. 7907-7912, 2015.

[31] Y. M. Shin, S.-Y. Jo, J.-S. Park, H.-J. Gwon, S. I. Jeong, and Y.-M. Lim, "Synergistic effect of dual-functionalized fibrous scaffold with BCP and RGD containing peptide for improved osteogenic differentiation," Macromolecular Bioscience, vol. 14, no. 8, pp. 1190-1198, 2014.

[32] A. J. García and C. D. Reyes, "Bio-adhesive surfaces to promote osteoblast differentiation and bone formation," Journal of Dental Research, vol. 84, no. 5, pp. 407-413, 2005. 
[33] L. G. Griffith and G. Naughton, “Tissue engineering-current challenges and expanding opportunities," Science, vol. 295, no. 5557, pp. 1009-1014, 2002.

[34] X. Liu and P. X. Ma, "Polymeric scaffolds for bone tissue engineering," Annals of Biomedical Engineering, vol. 32, no. 3, pp. 477-486, 2004.

[35] J. A. Burdick and K. S. Anseth, "Photoencapsulation of osteoblasts in injectable RGD-modified PEG hydrogels for bone tissue engineering," Biomaterials, vol. 23, no. 22, pp. 4315-4323, 2002.

[36] C. X. Guo, S. R. Ng, S. Y. Khoo, X. Zheng, P. Chen, and C. M. $\mathrm{Li}$, "RGD-peptide functionalized graphene biomimetic live-cell sensor for real-time detection of nitric oxide molecules," ACS Nano, vol. 6, no. 8, pp. 6944-6951, 2012.

[37] O. Akhavan, E. Ghaderi, and H. Emamy, "Nontoxic concentrations of PEGylated graphene nanoribbons for selective cancer cell imaging and photothermal therapy," Journal of Materials Chemistry, vol. 22, no. 38, pp. 20626-20633, 2012.

[38] J. T. Robinson, S. M. Tabakman, Y. Liang et al., "Ultrasmall reduced graphene oxide with high near-infrared absorbance for photothermal therapy," Journal of the American Chemical Society, vol. 133, no. 17, pp. 6825-6831, 2011.

[39] J. W. Park, S. J. Park, O. S. Kwon, C. Lee, and J. Jang, "Polypyrrole nanotube embedded reduced graphene oxide transducer for field-effect transistor-type $\mathrm{H}_{2} \mathrm{O}_{2}$ biosensor," Analytical Chemistry, vol. 86, no. 3, pp. 1822-1828, 2014.

[40] T.-W. Chung, Y.-C. Tyan, and J.-D. Yang, "PCP copolymers grafted with RGD enhance the rates of RGD-PCP micelles internalized into cells," Journal of Microencapsulation, vol. 27, no. 6 , pp. 514-520, 2010.

[41] A. Manickam, C. A. Johnson, S. Kavusi, and A. Hassibi, "Interface design for CMOS-integrated Electrochemical Impedance Spectroscopy (EIS) biosensors," Sensors, vol. 12, no. 11, pp. 14467-14488, 2012.

[42] M. Andrei, C. Pirvu, and I. Demetrescu, "Electrochemical impedance spectroscopy in understanding the influence of ultrasonic dental scaling on the dental structure-dental filling interface," European Journal of Oral Sciences, vol. 122, no. 6, pp. 411-416, 2014.

[43] R. N. Vyas and B. Wang, "Electrochemical analysis of conducting polymer thin films," International Journal of Molecular Sciences, vol. 11, no. 4, pp. 1956-1972, 2010.

[44] A. S. Karimullah, D. R. S. Cumming, M. Riehle, and N. Gadegaard, "Development of a conducting polymer cell impedance sensor," Sensors and Actuators B: Chemical, vol. 176, pp. 667-674, 2013.

[45] R. M. Nohutcu, L. K. McCauley, A. J. Koh, and M. J. Somerman, "Expression of extracellular matrix proteins in human periodontal ligament cells during mineralization in vitro," Journal of Periodontology, vol. 68, no. 4, pp. 320-327, 1997.

[46] L. B. Alves, V. C. Mariguela, M. F. M. Grisi et al., "Expression of osteoblastic phenotype in periodontal ligament fibroblasts cultured in three-dimensional collagen gel," Journal of Applied Oral Science, vol. 23, no. 2, pp. 206-214, 2015.

[47] C. R. Keese, J. Wegener, S. R. Walker, and I. Giaever, "Electrical wound-healing assay for cells in vitro," Proceedings of the National Academy of Sciences of the United States of America, vol. 101, no. 6, pp. 1554-1559, 2004.

[48] I. Giaever and C. R. Keese, "A morphological biosensor for mammalian cells," Nature, vol. 366, no. 6455, pp. 591-592, 1993.
[49] J. A. Stolwijk, C. Hartmann, P. Balani et al., "Impedance analysis of adherent cells after in situ electroporation: non-invasive monitoring during intracellular manipulations," Biosensors and Bioelectronics, vol. 26, no. 12, pp. 4720-4727, 2011.

[50] S. Arndt, J. Seebach, K. Psathaki, H.-J. Galla, and J. Wegener, "Bioelectrical impedance assay to monitor changes in cell shape during apoptosis," Biosensors and Bioelectronics, vol. 19, no. 6, pp. 583-594, 2004.

[51] S. Chen, R. Einspanier, and J. Schoen, "Transepithelial electrical resistance (TEER): a functional parameter to monitor the quality of oviduct epithelial cells cultured on filter supports," Histochemistry and Cell Biology, vol. 144, no. 5, pp. 509-515, 2015.

[52] B. Srinivasan, A. R. Kolli, M. B. Esch, H. E. Abaci, M. L. Shuler, and J. J. Hickman, "TEER measurement techniques for in vitro barrier model systems," Journal of Laboratory Automation, vol. 20, no. 2, pp. 107-126, 2015.

[53] D. D. Ateh, A. Waterworth, D. Walker, B. H. Brown, H. Navsaria, and P. Vadgama, "Impedimetric sensing of cells on polypyrrolebased conducting polymers," Journal of Biomedical Materials Research Part A, vol. 83, no. 2, pp. 391-400, 2007.

[54] I. Giaever and C. R. Keese, "Monitoring fibroblast behavior in tissue culture with an applied electric field," Proceedings of the National Academy of Sciences of the United States of America, vol. 81, no. 12 I, pp. 3761-3764, 1984.

[55] J. Hong, K. Kandasamy, M. Marimuthu, C. S. Choi, and S. Kim, "Electrical cell-substrate impedance sensing as a non-invasive tool for cancer cell study," Analyst, vol. 136, no. 2, pp. 237-245, 2011.

[56] K. Benson, S. Cramer, and H.-J. Galla, "Impedance-based cell monitoring: barrier properties and beyond," Fluids and Barriers of the CNS, vol. 10, no. 1, article 5, 2013.

[57] Y. Qiu, R. Liao, and X. Zhang, "Real-time monitoring primary cardiomyocyte adhesion based on electrochemical impedance spectroscopy and electrical cell-substrate impedance sensing," Analytical Chemistry, vol. 80, no. 4, pp. 990-996, 2008.

[58] Y. Yamaji, T. Kubota, K. Sasaguri et al., "Inflammatory cytokine gene expression in human periodontal ligament fibroblasts stimulated with bacterial lipopolysaccharides," Infection and Immunity, vol. 63, no. 9, pp. 3576-3581, 1995.

[59] A. Du, S. Zhao, L. Wan et al., "MicroRNA expression profile of human periodontal ligament cells under the influence of Porphyromonas gingivalis LPS," Journal of Cellular and Molecular Medicine, vol. 20, no. 7, pp. 1329-1338, 2016. 

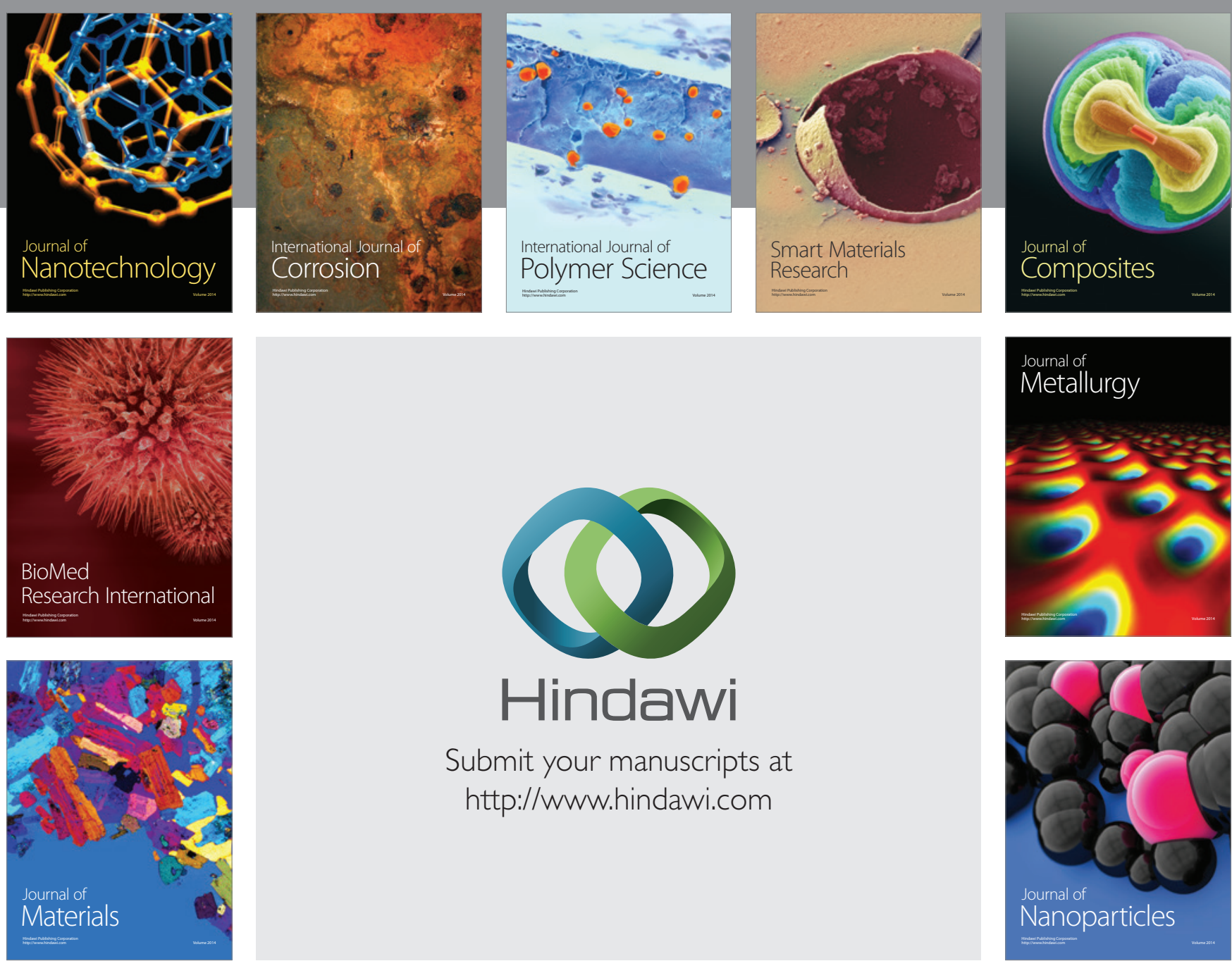

\section{Hindawi}

Submit your manuscripts at

http://www.hindawi.com

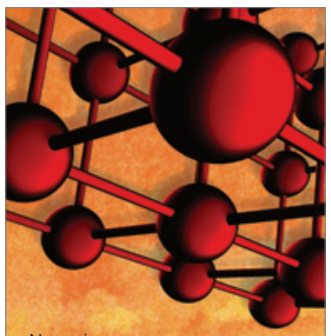

Materials Science and Engineering
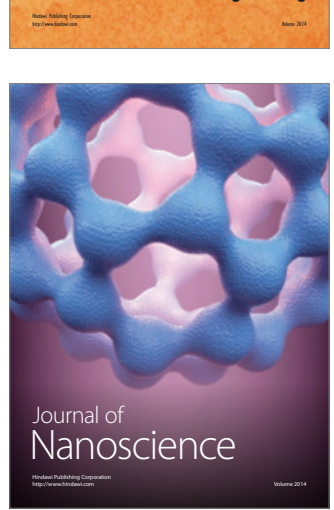
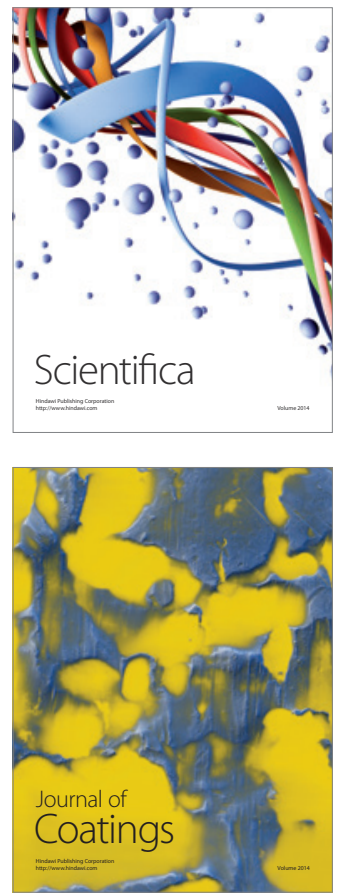
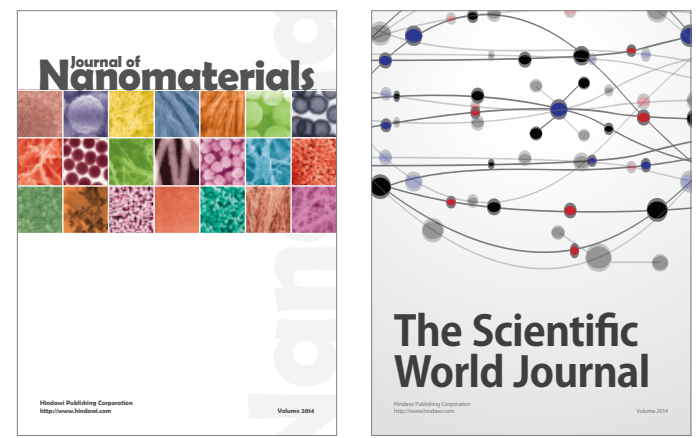

The Scientific World Journal
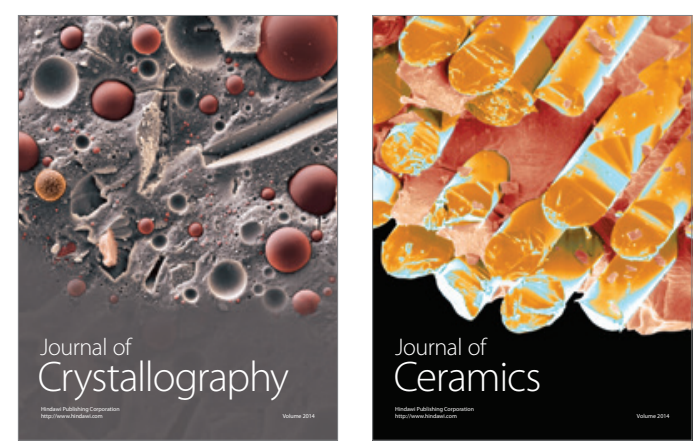
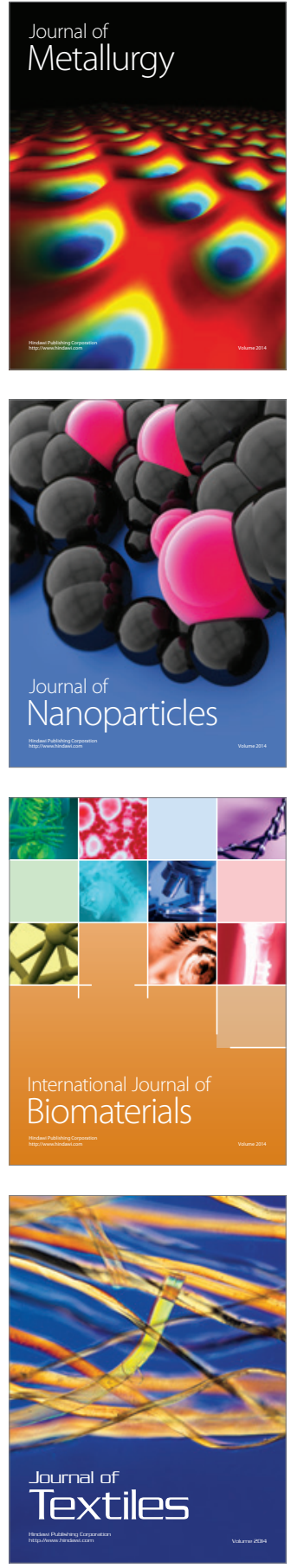